\title{
correspondence
}

\section{Future of journals}

SIR,-Your editorial of August 26 (p. 731) on the future of journals is typical of the current negative attitude to the problem. It is a pity that the more constructive contribution on the subject from Professor May and his wife (Nature, February 12, p. 446) was not mentioned.

The rising costs of running a library are eating into the money available for the purchase of publications, and yet we constantly read that there are too many journals, never too many librarians. The main library is often rightly the showpiece of the modern university campus, but are all librarians aware of their primary responsibility? Rows of expensively bound journals may satisfy the eye, but a drawer or binder of microfiche could be more relevant to academic needs.

The "pious hope" that two journals might be shut down for every new one launched would not be considered particularly pious by the users of the two guillotined journals. It would be more sensible in the short term to cut down on costs on both sides, amalgamate smaller, ailing periodicals and employ new methods such as those pioneered by the chemical societies in the United States and Britain.

We gather from various journal publishers that despite the economic conditions prevailing in many countries, reasonably priced research journals of medium circulations $(1,000-4,000$ subscribers) have generally enjoyed a steady increase in circulation, which has been maintained this year. This is an inevitable result of the worldwide growth of the academic community, and possibly also of the rationalisation of library purchases; for example, a university which may take 10 subscriptions to a major journal, or an 'essential title', for various departments, might cut down to two for the main libraries (Nature beware!), thus releasing funds for new acquisitions.

The long-term result of this trend might well be a huge number of journals distributed to, say, 1,000 resource/information centres scattered around the world. Researchers would then obtain photocopies of original papers, having browsed through synopses and abstracts, at their local library, by then reduced to little more than a post-office. This surely could lead to delays of a week or more. Faced with such a possible outcome perhaps researchers and librarians might learn to love cabinets of microfiche.

May we therefore suggest that the present number of 35,000 journal titles should be viewed as a challenge, and not approached with despair. The final suggestion in your editorial, that authors should supply full details on request, would be a long step backwards. Imagine trying to trace an author from his last known address; with the present postal services it could take months. Who would be prepared to referee papers which might never be read? What use would data lists be in job applications? Evidence could be altered at a later date as no dated record would exist. Such chaos should be avoided. More organisation is required, not less. Peter Ashby

Robert CAMPBell

Oxford Microfilm Publications Ltd. Oxford $O X I 4 E Y, U K$

SIR,-I should like to comment on your editorial about the future of journals (August 26). As librarian in a research laboratory, I would agree with most of what you say - with the proviso that the changes you refer to should be reflected not only in journal subscription price, but in volume of paper. This is conspicuously not the case in the experiment of the American Chemical Society, where the weight of paper is much higher in the experimental than in the traditional journal.

As a practising organic chemist, I must, however, reply a firm "no" to your last question. Chemistry in general, and organic chemistry in particular, is an experimental science, and we must have the experimental detail readily available. One of the greatest weaknesses of the Bulletin de la Société Chimique de France was that experimental sections were abbreviated to the point of irreproducibility, although things have improved recently. There is a large body of opinion (perhaps even a majority) which recognises that theoretical sections are usually fitted to experimental sections after the event; and indeed, what some would like to see is a journal in which only the experimental section and the literature list is printed, the theoretical section being available on microfiche if the reader were unable to supply his own! Alan F. Thomas

Firmenich $S A$, Geneva 8, Switzerland

\section{Mistaken impression}

SIR-I fear that Wil Lepkowski, in quoting from a paper that I presented at the Conference on Tradition and Change in Physics Graduate Education at Pennsylvania State University in August 1974, may have inadvertently given a mistaken impression of my position (August 12, page 528).

As I state in the same paper, "The Berkeley Group missed out on making these discoveries not so much in spite of the fact that their laboratory was so large, efficient, well-run and wellmanaged as precisely because of it".

The purpose of my paper was not to criticise a particular laboratory, but to argue, on the basis of historical experience, that the techniques of "Big Science", while they may be useful in solving certain engineering problems, as in the case of the Manhattan Project or the Apollo Program, are by their very nature not conducive to the making of fundamental, new scientific discoveries. Condensations of my paper were published in New Scientist, 63, 462 (1974) and Center Magazine, 55 (MayJune 1975).

\section{Memorial University of \\ Newfoundland, \\ Canada AlC 5S7}

Robert J. Yaes

\section{Biological fly killer?}

Sir,-The news on Human Tryponosomiasis Today by F. E. G. Cox (Nature, August 19, p. 646) calls for some views. As long as the immunological control of sleeping sickness remains unlikely, eradication of the genus Glossinia seems to be the only way to control the disease. Cox cited recent successes in Nigeria where a riverine area of $27,500 \mathrm{~km}^{2}$ was sprayed aerially. The same technique was recently used over parts of Bangladesh in an attempt to control mosquitoes. The disappearance of quite a number of insect species was subsequently noticed, though all of them may well have made a come back, and for sure the mosquitoes did. Bearing in mind the delicacy of ecological balances nobody should be satisfied with aerial spraying as a method of controlling insect species. Intensive efforts should be mounted to introduce methods of biological control, such as releasing specific pathogens.

K. M. S. Azız

Cholera Research Laboratory,

Dacca-2, Bangladesh 